\title{
MORINDA LUCIDA REDUCES CONTRACTILITY OF ISOLATED UTERINE SMOOTH MUSCLE OF PREGNANT AND NON-PREGNANT MICE
}

\author{
S. O. ELIAS, C. O. LADIPO *, B. P. ODUWOLE **, P. M. EMEKA ***, \\ P. D. OJOBOR * and O. A. SOFOLA *
}

Departments of Physiology, Lagos State University College of Medicine, P.M.B. 21266, Ikeja, Lagos.

* Department of Physiology, College of Medicine, University of Lagos, Idi-Araba, Lagos

**Department Parasitology, Lagos State University Teaching Hospital, Ikeja, Lagos

*** Department of Pharmacology, College of Medicine, University of Lagos, Idi-Araba, Lagos

E-mail: soelias2@yahoo.co.uk, Tel: 234-803-7149383

\begin{abstract}
Summary: The present work investigated the effect of Morinda lucida (M. lucida) extract on isolated uterine smooth muscle of pregnant and non-pregnant mice. Pregnant and non-pregnant mice were pretreated with oral stilboesterol $(0.1 \mathrm{mg} / \mathrm{kg}$ body weight $)$ and killed by cervical dislocation. Thin strips of the uterus were cut and mounted in a 20-ml organ bath containing De Jalon solution bubbled with $95 \% \mathrm{O}_{2}-5 \% \mathrm{CO}_{2}$ gas mixture. The strips were connected to a force transducer coupled to a Grass 7D Polygraph for the recording of isometric tension. Effects of graded concentrations of oxytocin (OXY; $\left.10^{-5}-10^{-2} \mathrm{~mol} / \mathrm{L}\right)$, acetylcholine ( $\left.\mathrm{ACh} ; 10^{-9}-10^{-5} \mathrm{~mol} / \mathrm{L}\right)$ and M. lucida extract $(0.015-1.5 \mathrm{mg} / \mathrm{ml})$ were recorded. Fresh uterine strips were then incubated with $M$. lucida extract for $5 \mathrm{mins}$ and cumulative response to OXY was repeated. Another set of fresh strips was incubated in L-NAME for 15mins and the cumulative responses to M.lucida extract were repeated. OXY resulted in increased contractile responses in both pregnant and non-pregnant uterine muscles. M. lucida resulted in relaxation of the uterine smooth muscle in both pregnant and non-pregnant mice at all doses. However, at $1.500 \mathrm{mg} / \mathrm{ml}$, M. lucida completely blocked spontaneous uterine contractions. Following incubation with L-NAME, M. lucida extract led to a slightly greater relaxation of the uterine strips. In conclusion, M. lucida reduced contractility of uterine smooth muscle in both pregnant and non-pregnant mice as well as blocking contractile responses to OXY and Ach in uterine smooth muscle of pregnant and nonpregnant mice. There was no significant alteration of $M$. lucida activity by L-NAME suggesting that the action of the compound on uterine muscle is not associated with impaired nitric oxide synthase.
\end{abstract}

Key Words: Morinda lucida, uterine contraction, nitric oxide, mice

\section{Introduction}

Morinda lucida (L.) Benth. (Rubiacae) is used in herbal decoctions in the treatment of "fevers" Sittie et al (1999), Lemmich et al (1999), malaria Watt (1962); Beyer-Bradwijk (1962) and diabetes Ettarh and Emeka (2004) in Africa. It has been reported that the main compounds that have useful antimalarial activities, which can be extracted from the stem bark and root of $\mathrm{M}$ lucida Benth are anthraquinones, digitolutein, rubiadin 1-methyl ether and damnacanthal Sittie et al (1999); Lemmich et al (1999); Koumaglo et al (1992). It has been shown that anthraquinones also have antibacterial properties (Koumaglo et al, 1992).

Studies have shown that administration of chloroquine to mice infected with Plasmodium yoeli nigeriensis parasites led to the survival of all the mice, while those treated with medicinal plants such as $M$. lucida exhibited various degrees of chemosuppression, which did not however lead to their survival (Agomo et al, 1992). Also, M. lucida has been reported to induce relaxation of vascular smooth muscle via endothelium-dependent and -independent mechanisms, the former of which involves the nitric oxide-cGMP pathway (Ettarh and Emeka, 2004).

Whereas these herbal preparations are widely used in pregnancy, not many reports have taken into consideration the effect of $M$. lucida on the uterus, pregnant or non-pregnant. We therefore investigated the effect of $M$. lucida on isolated uterine smooth muscle from non-pregnant and pregnant mice and the 
possible role of nitric oxide in its mechanism of action.

\section{Materials and Methods}

Plant

M. lucida fresh leaves were collected in Lagos, Nigeria in March 2002 and authenticated by Prof. D. Olowokudejo of Department of Botany and Microbiology, University of Lagos, Akoka, Lagos, Nigeria.

\section{Preparation of Extract}

Leaves of ground M. lucida that have been previously dried, weighing $250 \mathrm{~g}$ were Soxhletextracted with water. The extract was concentrated under vacuum at $40^{\circ} \mathrm{C}$, and appropriate stock solutions prepared on the day of the experiment.

\section{Animal Preparation}

The experiments were performed on 10 pregnant and 10 non-pregnant mice, which were obtained from the Laboratory Animal House Department of the Lagos State University College of Medicine. They were provided with mice pellets and water ad libitum. The mice were pretreated with $0.1 \mathrm{mg} / \mathrm{kg}$-body weight of stilboesterol given orally 24 hours before the experiment.

\section{Preparation of Mice Uterine Strips}

The mice were anaesthetized with urethane and sacrificed by cervical dislocation. The uterine horn was exposed by means of blunt dissection, freed of connective tissue and cut into strips of $2 \mathrm{~mm}$ long. The strip was suspended on fine stainless steel stirrups in a 20 $\mathrm{ml}$ organ bath and connected to a force transducer (Grass Model FT03), which was coupled to a 4-channel Grass Model 7D Polygraph for the recording of the isometric tension. The transducer was calibrated with $1 \mathrm{~g}$ weight to give a $2 \mathrm{~cm}$ paper deflection. The bath contained De Jalon solution Gamaniel et al (1995) of the following composition (1 L): $\mathrm{NaCl}-9 \mathrm{~g}, \quad \mathrm{NaHCO}_{3}-0.5 \mathrm{~g}, \quad$ Glucose-0.5g $10 \%$ $\mathrm{KCl}-4.2 \mathrm{ml}, 1 \mathrm{M} \mathrm{CaCl}-0.27 \mathrm{ml})$. The solution $\begin{array}{llllll}\text { was bubbled with a } 95 \% & \mathrm{O}_{2}-5 \% & \mathrm{CO}_{2} & \text { gas }\end{array}$ mixture. The temperature and $\mathrm{pH}$ were maintained at $37^{\circ} \mathrm{C}$ and $7.4 \pm 0.2$ respectively

\section{Experimental Protocols}

Each tissue preparation was allowed to equilibrate for 60-90 min under a resting tension of $9.5 \mathrm{mN}$. All investigations were carried out in spontaneously contracting uterine strips. Graded concentrations of oxytocin (OXY) $10^{-5}-10^{-2}$ $\mathrm{mol} / \mathrm{L}$ were added into the organ bath and their effects noted. In addition, responses to graded concentrations of the following were investigated in fresh uterine strips from different mice after the equilibration period: acetylcholine (ACh; $10^{-9}-10^{-5} \mathrm{~mol} / \mathrm{L}$ ) and $M$. lucida $(0.015-1.500 \mathrm{mg} / \mathrm{ml})$. The tissues were then incubated in $1.500 \mathrm{mg} / \mathrm{ml}$ of $M$. lucida for 5 minutes after which the cumulative dose responses to OXY and ACh were repeated. Finally, graded dose response to M. lucida was investigated in different sets of tissues from different animals after incubation in $10^{-4} \mathrm{M} \mathrm{N}^{\omega}$ nitro L-arginine methyl ester (L-NAME) for 15 minutes.

\section{Statistics}

For each cumulative dose response study, the $\mathrm{EC}_{50}$ values were calculated. The data are presented as means \pm SEM and Student's unpaired t-test was used to test for statistical differences among groups. $\mathrm{P}$ value less than 0.05 was considered significant.

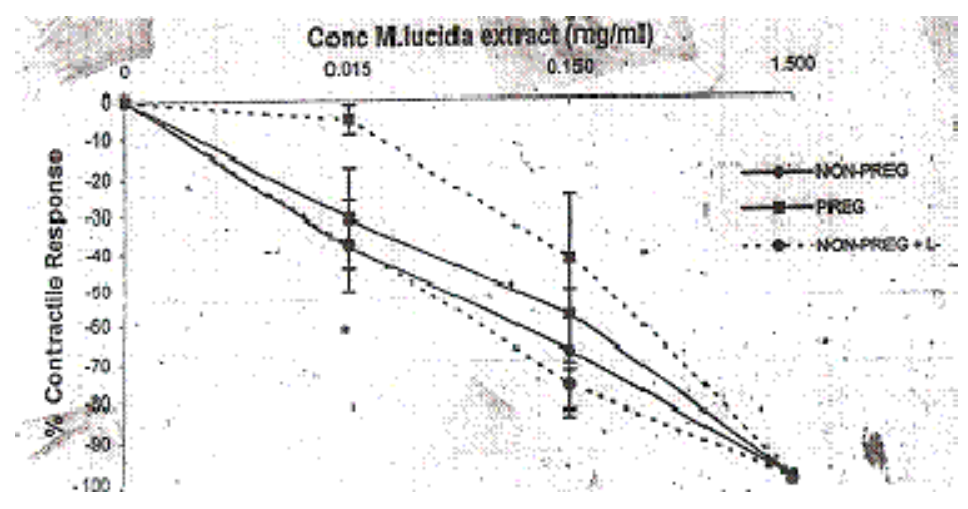

Figure 1: Typical tracing of the effect of administration of: (1)-M lucida alone, (2)-M lucida after incubation with L-NAME, (3)-Oxytocin after incubation with M lucida and (4)-Acetylcholine after incubation with $M$ lucida, in uterine strips of (a)-non-pregnant and (b)-pregnant mice respectively. 
Table 1: $E C_{50}$ and Maximum Tension Response $(\mathrm{mN})$ due to administration of $M$ lucida before and after incubating in L-NAME in non-pregnant and pregnant mice

\begin{tabular}{lllll}
\hline & \multicolumn{3}{l}{ M. lucida alone } & \multicolumn{2}{l}{ M. lucida with L-NAME } \\
\hline & $\begin{array}{l}\text { Non- } \\
\text { Pregnant } \\
(\mathrm{n}=5)\end{array}$ & $\begin{array}{l}\text { Pregnant } \\
(\mathrm{n}=7)\end{array}$ & $\begin{array}{l}\text { Non-Pregnant } \\
(\mathrm{n}=5)\end{array}$ & $\begin{array}{l}\text { Pregnant } \\
(\mathrm{n}=7)\end{array}$ \\
$\begin{array}{l}0.052 \pm 0.02 \\
\mathrm{EC}_{50}\end{array}$ & $0.105 \pm 0.04$ & $0.001 \pm 0.00$ & $0.245 \pm 0.10$ \\
$(\mathrm{mg} / \mathrm{ml})$ & $8.28 \pm 1.70$ & $6.74 \pm 0.73$ & $7.19 \pm 1.13$ & $5.47 \pm 0.54$ \\
$\begin{array}{l}\text { Maximum } \\
\text { Response } \\
(\mathrm{mN})\end{array}$ & & & & \\
\hline
\end{tabular}

\section{Results}

Effect of M. lucida on Mice Uteri

All doses of $M$. lucida led to relaxation of spontaneous uterine contraction in non-pregnant and pregnant mice. However, there was no difference in the $\mathrm{EC}_{50}$ and maximum response of uterine smooth muscle of non-pregnant and pregnant mice to M. lucida (Table I). Also, the frequency of contraction to $M$. lucida in the uterine strips of the experimental mice was similar (Figure 1).

Table 2: Effect of $M$ lucida incubation on uterine spontaneous contractile response (\%) to (a) oxytocin $(O X Y)$ and (b) acetylcholine (ACh) in non-pregnant and pregnant mice ifrequency of spontaneous uterine contraction (contraction per min) in parenthesis\}

(a)

\begin{tabular}{lllll}
\hline & \multicolumn{2}{c}{ Non-Pregnant $(\mathrm{n}=5)$} & \multicolumn{2}{c}{ Pregnant $(\mathrm{n}=6)$} \\
\hline $\begin{array}{l}\text { Dose } \\
(\mathrm{IU} / \mathrm{ml})\end{array}$ & OXY alone & $\begin{array}{l}\text { OXY with } \\
\text { M lucida }\end{array}$ & OXY alone & $\begin{array}{l}\text { OXY with } \\
\text { M lucida }\end{array}$ \\
$10^{-5}$ & $23.68 \pm 12.93$ & $0.00 \pm 0.00$ & $30.15 \pm 14.20$ & $0.06 \pm 0.04$ \\
& $(0.78 \pm 0.34)$ & $(0.00 \pm 0.00)$ & $(0.49 \pm 0.29)$ & $(0.08 \pm 0.05)$ \\
$10^{-4}$ & $40.69 \pm 17.44$ & $0.06 \pm 0.02$ & $47.33 \pm 17.53$ & $0.30 \pm 0.05)$ \\
& $0.92 \pm 0.59)$ & $0.16 \pm 0.09)$ & $(0.49 \pm 0.32)$ & $(0.48 \pm 0.25)$ \\
$10^{-3}$ & $67.12 \pm 19.36$ & $0.12 \pm 0.09$ & $77.49 \pm 11.28$ & $1.06 \pm 0.51$ \\
& $(0.86 \pm 0.34)$ & $(0.12 \pm 0.08)$ & $(0.97 \pm 0.58)$ & $(1.60 \pm 0.72$ \\
$10^{-2}$ & $90.00 \pm 10.00$ & $0.20 \pm 0.09$ & $84.87 \pm 10.03$ & $2.18 \pm 0.71$ \\
& $(0.98 \pm 0.55)$ & $(0.08 \pm 0.05)$ & $(1.09 \pm 0.50)$ & $(2.32 \pm 0.69)$ \\
\hline
\end{tabular}

$* P<0.05$ vs. non-pregnant uterine treated with M lucida

(b)

\begin{tabular}{lllll}
\hline \multicolumn{2}{c}{ Non-Pregnant $(\mathrm{n}=5)$} & \multicolumn{1}{c}{ Pregnant $(\mathrm{n}=6)$} \\
\hline $\begin{array}{l}\text { Dose } \\
(\mathrm{M})\end{array}$ & ACh alone & $\begin{array}{l}\text { ACh with } M \\
\text { lucida }\end{array}$ & ACh alone & $\begin{array}{l}\text { ACh with } \\
\text { M lucida }\end{array}$ \\
$10^{-9}$ & $5.49 \pm 2.64$ & $0.00 \pm 0.00$ & $-27.47 \pm 15.72$ & $0.00 \pm 0.00$ \\
& $(0.78 \pm 0.34)$ & $(0.00 \pm 0.00)$ & $(0.78 \pm 0.34)$ & $(0.00 \pm 0.00)$ \\
$10^{-8}$ & $21.46 \pm 7.30$ & $0.00 \pm 0.00$ & $-25.62 \pm 11.11$ & $0.00 \pm 0.00$ \\
& $0.92 \pm 0.59$ & $(0.00 \pm 0.00)$ & $(0.92 \pm 0.59)$ & $(0.00 \pm 0.00)$ \\
$10^{-7}$ & $22.07 \pm 9.14$ & $0.00 \pm 0.00$ & $1.08 \pm 0.49$ & $0.00 \pm 0.00$ \\
& $(0.86 \pm 0.34)$ & $(0.00 \pm 0.00)$ & $(0.86 \pm 0.34)$ & $(0.00 \pm 0.00)$ \\
$10^{-6}$ & $49.00 \pm 16.81$ & $0.08 \pm 0.05$ & $37.51 \pm 14.24$ & $0.00 \pm 0.00$ \\
& $(0.98 \pm 0.55)$ & $(0.02 \pm 0.01)$ & $(0.98 \pm 0.55)$ & $(0.00 \pm 0.00)$ \\
$10^{-5}$ & $100.00 \pm 0.00$ & $0.08 \pm 0.05$ & $100.00 \pm 0.00$ & $1.12 \pm 0.46$ \\
& $(0.98 \pm 0.55)$ & $(0.02 \pm 0.01)$ & $(0.98 \pm 0.55)$ & $(0.96 \pm 0.39)$ \\
\hline
\end{tabular}




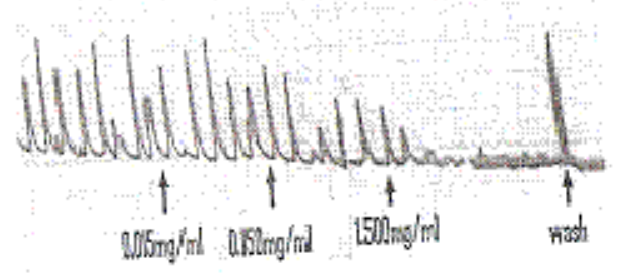

la)

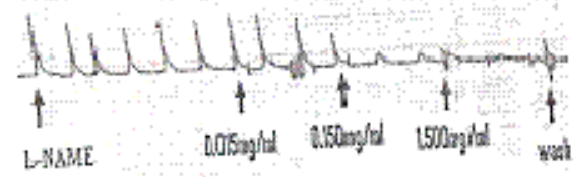

2(a)

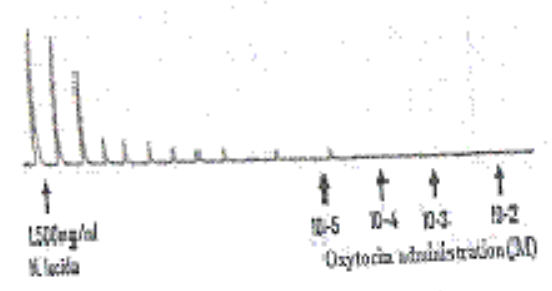

3 (a)

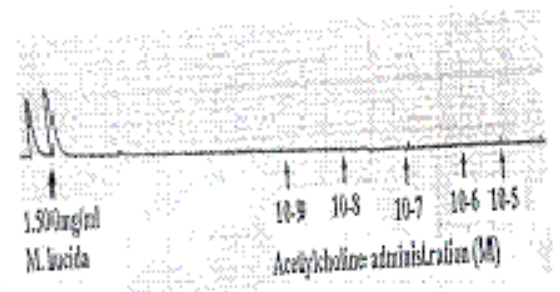

5. $4(a)$

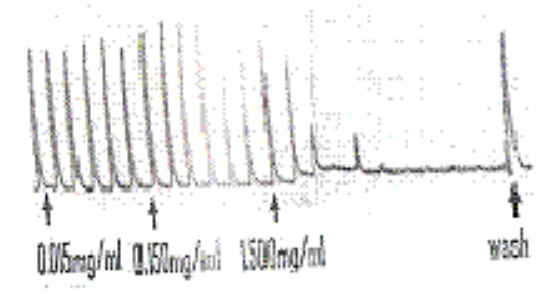

I(b)

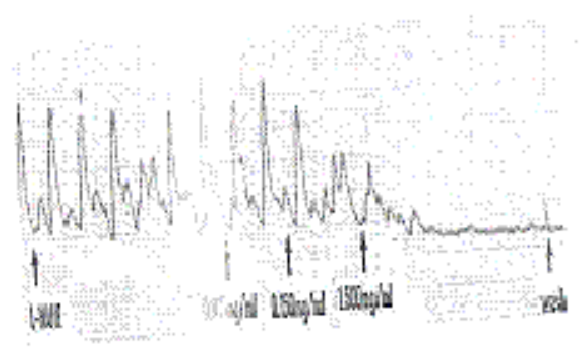

2(b)
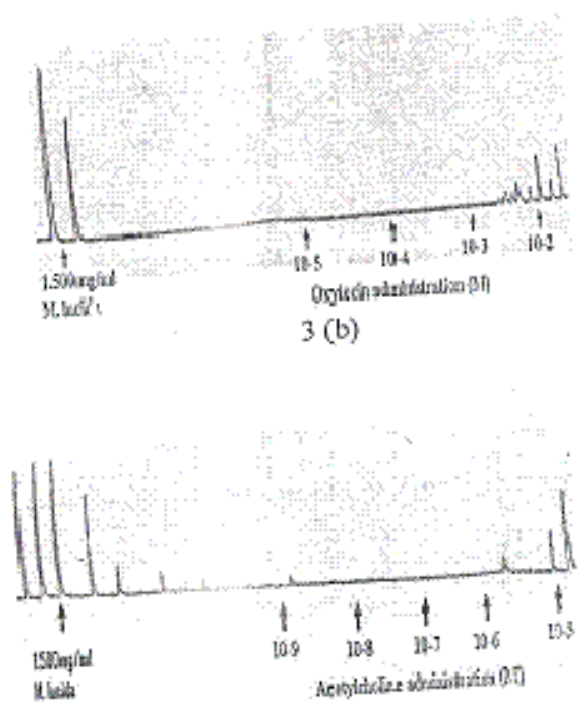

4 (b)

Figure 2: Line graph showing responses to M. lucida in uterine strips of (a) non-pregnant mice (Non-Preg, $n=5)$, (b) pregnant mice (Preg, $n=7)$, (c) non-pregnant mice (Non-P) after incubating in $L-N A M E$; and $(d)$ pregnant mice (Preg, $n=7)$ after incubating in L-NAME. Each point represents a mean of the observation \pm S.E.M 
Effect of M. lucida on Responses of Uterine Strips to $O X Y$ and $A C h$

Incubation in M. lucida $(1.50 \mathrm{mg} / \mathrm{ml})$ led to total blockade of contractile response to OXY in non-pregnant uterine strips of non-pregnant mice while uterine strips of pregnant mice produced slight contractile responses to $10^{-4}$ $10^{-2} \mathrm{IU} / \mathrm{ml}$ of OXY (Table IIa). There was a significantly higher $(\mathrm{P}<0.03)$ degree and frequency of contractile response to $10^{-2} \mathrm{IU} / \mathrm{ml}$ of OXY in pregnant uterine strips of pregnant mice compared with uterine strips of nonpregnant mice (Figure 1). However, incubation with $M$. lucida led to complete inhibition of contractile response to $\mathrm{ACh}$ in experimental mice (Figure 1).

Effect of L-NAME on Responses of Isolated Uterine Smooth Muscles to M. lucida in Experimental Mice

There was a shift to the right in the dose response curve to $M$. lucida in pregnant mice (Figure 1) after incubation of the uterine strips in L-NAME $\left(10^{-4} \mathrm{M}\right)$ for 15 minutes. Also, relaxant effect of $M$. lucida on the strips at low dose $(0.015 \mathrm{mg} / \mathrm{ml})$ in the presence of L-NAME was significantly $(\mathrm{P}<0.05)$ attenuated. However, there was no significant difference in $\mathrm{EC}_{50}$ and maximum response to $M$. lucida alone or $M$. lucida with L-NAME in both groups (Table I).

\section{Discussion}

The present experiments have shown that M. lucida has a relaxant effect on uterine smooth muscle of both non-pregnant and pregnant mice; inhibiting both the degree and frequency of contractile responses. There was no significant difference in the sensitivity of the uterine strips to $M$. lucida in non-pregnant or pregnant mice.

M. lucida at a concentration of 1.500 $\mathrm{mg} / \mathrm{ml}$ completely blocked the cumulative responses of the uterine strips to OXY $\left(10^{-5}-10^{-2}\right.$ $\mathrm{IU} / \mathrm{L})$ and $\mathrm{ACh}\left(10^{-9}-10^{-5} \mathrm{~mol} / \mathrm{L}\right)$ in both pregnant and non-pregnant mice. However, there was a slight contractile response in uterine smooth muscle of pregnant mice to high dose of OXY $\left(10^{-2} \mathrm{IU} / \mathrm{L}\right)$ and ACh $\left(10^{-5} \mathrm{M}\right)$, which was significantly greater than those observed in uterine smooth muscles of non-pregnant mice. This might probably be due to increase in OXY receptors associated with pregnancy Silverthorn (2004), which may have been responsible for this observation in pregnant mice.

Anti-malarial drugs like chloroquine have been reported to possess inhibitory action on the uterus (Nwaigwe et al, 1997). In many cases, chloroquine has been abused with its local use as an abortifacient effect without regards for its associated toxic effect (Raddy and Sinna, 2000).
M. lucida is used for the treatment of malaria Sittie et al (1999), Lemmich et al (1999); Watt (1962), Beyer-Bradwijk (1962) and it is found to be cytotoxic, with $\mathrm{LC}_{50}$ values of $2.6 \mu \mathrm{g} / \mathrm{ml}$ (Ajaiyeoba et al, 2006). Earlier works have reported that $M$. lucida has a vasorelaxant effect on vascular smooth muscle, which is due to endothelium-dependent and -independent mechanisms, the former of which involves the nitric oxide-cGMP pathway (Ettarh and Emeka, 2004). Endothelial cells produce factors like nitric oxide (NO), prostacyclin and the endothelium-derived hyperpolarizing factor, which mediate the endothelium-dependent relaxation (Vapaatalo and Mervaala, 2001). The L-arginine-NO system has been demonstrated as possessing inhibitory effect on myometrial contractility (Kaya and Sarioglu, 1998). However, nitric oxide synthase inhibition appears to have no significant effect on $M$. lucida action on myometrial contractility in the present study.

In conclusion, this study demonstrates that M. lucida has a relaxant effect on isolated uterine smooth muscle of both non-pregnant and pregnant mice. This observation appears to be independent of bioavailability of nitric oxide in the uterus. However, further work investigating the effect of M. lucida on calcium mobilization from intracellular or extracellular stores will need to be explored.

\section{References}

Agomo, P. U., Idigo, J. C., Afolabi, B. M. (1992). 'Antimalarial' medicinal plants and their impact on cell populations in various organs of mice. Afr. J. Med. Med. Sci. 21: 3946.

Ajaiyeoba, E. O., Abiodun, O. O., Falade, M. O., Ogbole, N. O., Ashidi, J. S., Happi, C. T. and Akinboye, D. O. (2006). In vitro cytotoxicity studies of 20 plants used in Nigerian antimalarial ethnomedicine. Phytomedicine. 13:295-298.

Ettarh, R. R., Emeka, P. (2004). Morinda lucida extract induces endothelium-dependent and -independent relaxation of rat aorta. Fitoterapia 75: 332-336.

Gamaniel, K., Ojo, T., Wambebe, C., Awodogan. A., Samson, A., Shittu, A., Vangtau, H., Azuine, M. A. and Akah, P. A. (1995). New cytotoxic quinazoline derivatives that relax the isolated rat uterus and the rabbit ileum. West Afr. J. Pharmacol. Drug Res. 11: 80-86.

Kaya, T., Cetin, A. and Sarioglu, Y. (1998). Changes in the nitric oxide system of rat myometrium during midgestation and delivery at term. Pharmacol Res. 37: 403408. 
Koumaglo, K., Gbeassor, M., Nikabu, O., de Souza, C., Werner, W. (1992). Effect of three compounds extracted from morinda lucida on Plasmodium falciparum. Planta. Med. 58: 533-4.

Nwaigwe, C. I., Adegunloye, B. J. \& Sofola, O. A. (1997). Effect of chloroquine on the contractility of the smooth muscle of the rat uterus, trachea and urinary bladder. $J$. Basic. Clin. Physiol. Pharmacol. 8: 279285

Raddy, V. G. and Sinna. S. (2000). Chloroquine poisoning: report of two cases. Acta Anaesthesiol Scand 44: 1017-1020.

Silverthorn, D. U. (2004). Pregnancy and parturition in Human Physiology: An Integrated Approach (third edition) pp 821828, Pearson Education, Inc.
Sittie, A. A., Lemmich, E. and Oslen, C. E. (1999). Structure-activity studies: in-vitro antileishmanial and antimalaria activity of anthraquinous from Morinda lucida. Planta. Med. 65: 259-61.

Vapaatalo, H. and Mervaala, E. (2001). Clinical important factors influencing endothelium function. Med. Sci. Monit. 7: 1075-1085.

Watt, J. M., Beyer-Bradwijk, M. G. (1962). The medicinal and poisonous plants of Southern and Eastern Africa. London: E.S. Livingstone Ltd.

Received: 18/9/2006

Accepted: 18/12/2007 